DOI https://doi.org/10.30525/978-9934-26-006-3-23

\title{
ЗАГАЛЬНІ МЕТОДИКИ ЛІКУВАННЯ, ПРОЦЕДУРИ У КОСМЕТИЧНОМУ КАБІНЕТІ ДЕРМАТОЛОГІЧНИХ ДЕФЕКТІВ ШКІРИ ПРИ РОЗАЦЕА
}

\author{
Бобро С. Г. \\ кандидат фармачевтичних наук, \\ старший викладач кафедри косметології і аромології \\ Національний фармащевтичний університет \\ Башура О. Г. \\ доктор фармачевтичних наук, професор, \\ завідувач кафедри косметології і аромології \\ Начіональний фармацевтичний університет \\ Миргород В. C. \\ асистент кафедри косметологї і аромології \\ Національний фармачевтичний університет \\ м. Харків, Украӥна
}

Як купероз, так і розацеа характеризуються почервонінням шкіри. Однак простим відмітною ознакою $є$ те, що при купероз поверхню шкіри зазвичай гладка і видно судинні сіточки, а при розацеа шкіра зазвичай запалена, з ущільненнями або гнойничками (через що іноді іiі плутають із захворюванням акне). Протягом куперозу прийнято виділяти чотири стадії. Пацієнти відзначають дискомфорт - свербіж, печіння, поколювання, почервоніння, підвищення чутливості шкіри ще до появи клінічних ознак телеангіоектазій.

Але мало хто звертається за допомогою до косметолога на початковій стадії $[2,4]$. Клінічним проявом служить стійка гіперемія ураженої зони. Саме іiі тривалість і дозволяє відрізнити купероз від еритроза - функціонального почервоніння шкіри у відповідь на провокуючі фактори, такі як прийом гарячої їжі, стрес, алкоголь, температурні зміни, що носять транзиторний характер.

На першої стадії виникають симптоми купероза: відчуття жару, припливи крові до обличчя, почервоніння шкіри, спочатку короткочасні. На даному етапі судинна стінка ще досить еластична i здатна скоротитися до вихідного стану. Об'єктивно ми бачимо два-три 
розширених капіляра на фоні еритеми. Переважно вони локалізуються в області крил носа, на щоках або центральній частині підборіддя $[1,3,5]$.

На другій стадії патології капіляри об'єднуються в сіточку і стають яскравішими. 3'являється стійка гіперемія над ураженими ділянками.

Третя стадія характеризується окремими або множинними телеангіектазіями на фоні застійної еритеми, 3 чітко видимими капілярами. Локалізовані вони переважно в центральній частині обличчя.

Четверту стадію характеризують залучення практично всіх судин обличчя, поява ділянок блідої шкіри внаслідок спазмування судин $[4,6]$. Пацієнти звертають увагу на зміну кольору шкіри, тенденцію до iii сухості, підвищення порога чутливості, що періодично з'являються запальні елементи, пастозність шкіри $[3,5]$.

Загальні методики лікування, процедури у косметичному кабінеті.

Лікування куперозу заключає в себе декілька аспектів. Виходячи 3 патогенезу, слід проводити його в залежності від стадії процесу i керуватися комплексним підходом до проблеми. При виявленні соматичних захворювань або підозрі на їх наявність, необхідні консультація і подальше лікування профільними фахівцями - для усунення причини недуги. В іншому випадку всі найновітніші методики будуть приносити лише тимчасовий естетичний ефект. Необхідно дотримання певних рекомендацій, що стосуються способу життя, харчування, відмови від шкідливих звичок, догляду за шкірою. Рекомендації ці виключають дію факторів, які провокують ламкість судин, і спрямовані на зміцнення судинної стінки:

- Відмова від термічних впливів на шкіру обличчя (лазні, солярії, вапоризатори, інгаляції і т. д.) $[1,4,6]$.

- Застосування засобів щадного догляду, відмова від спиртовмісних, судинорозширювальних, агресивних компонентів (ментол, ефірні масла, фруктові кислоти і т. д.).

- Використання сонцезахисту для чутливої шкіри не тільки в літню пору.

- Виняток грубого механічного впливу на шкіру (скраби, щіточки для вмивання, плівкоутворювальні маски).

- Корекція дієти (відмова від надто гарячих їжі та напоїв, від алкоголю, прянощів, гострого, жирного, газованих напоїв, збільшення кількості продуктів, багатих на вітаміни С i $\mathrm{K}$, поліненасиченими жирними кислотами) [5, 7]. 
Додатково призначаються речовини, які зміцнюють судинну стінку: вітамін С, рутин, екстракт гінкго білоба, троксерутин, жирні кислоти Омега-3 і Омега-6.

Засоби медичної косметології: лімфодренажні масажні методики; заспокійливі і капіляростабілізуючі засоби (в залежності від стадії процесу - зовнішньо або мезотерапевтичні); діатермокоагуляцію; світлові методи лікування (склерозування розширених капілярів лазером, фототерапія); озонотерапію; кріомасаж.

При призначенні лікування точні рекомендації залежать, безумовно, від конкретного пацієнта і його стану, від стадії процесу, супутньої патології. Тільки комплексний підхід і спільна робота косметолога і клієнта гарантують стійке поліпшення стану або повне вилікування $[1,3]$.

\section{Процедури в косметологічному кабінеті:}

Фототерапія з використанням технології IPL. IPL - технологія інтенсивного імпульсного широкосмугового світла, що представляє собою пучок широкосмугового світла $[1,4,7]$.

Склеротерапія - принцип полягає у введенні в уражену судину спеціального препарату, який поступово склеює i запаює його. Перевагою є малотравматичність маніпуляції $[4,7]$.

Електрокоагулячія - принцип полягає у впливі електричного струму на судини. Видаляти судинні зірочки на обличчі електрокоагуляцією не рекомендується. Для видалення телеангіоектазій цим методом достатньо всього однієї процедури $[3,5,7]$.

Застосування методу радіохвильової хірургії - для видалення використовують електромагнітне поле радіохвиль, точніше вплив за допомогою струмів високої частоти. Метод дуже схожий 3 електрокоагуляції, але ця технологія менш травматична, не викликає побічних явищ у вигляді набряків і рубцювання $[1,5]$.

Озонотерапія - в основі методу лежить введення в судини озонокисневої суміші 3 високим вмістом озону. Суміш 3 озоном має здатність запускати окислювальні процеси в судинах, що згодом призведе до руйнування стінок судин.

Лазерне видалення судин - вплив відбувається за допомогою монохроматичного променя, точніше діє світло 3 однієї певною довжиною хвилі. Ця дія вузьконаправлена і високоефективна $[2,4,5]$.

Мезотерапія - це ін'єкції зон ураження препаратів, що сприяють регенерації шкіри і іiї кращому харчуванню, що дозволяє впоратися 3 телеангіоектазіями. Для ін'єкцій можуть використовуватися як лікарські засоби, так і вітамінні коктейлі $[2,4]$. 
Мікрострумова терапія, навпаки, заснована на впливі низькочастотних струмів на пошкоджені тканини. Така терапія сприяє прискоренню обмінних процесів в клітинах шкіри обличчя, зняттю запалень, почервонінь. Мікрострумова терапія допустима будь-якому віці, вона не викликає хворобливих відчуттів $[1,6]$.

Електрофорез поєднує в собі методику звичайної гальванізації і введення з ії допомогою в організм іонів лікарської речовини $[1,3,6]$. В залежності від сили, місця і часу впливу гальванізацією можна домогтися підвищення або зниження функції тканин, поліпшення периферичного кровообігу, прискорення регенерації пошкоджених тканин, поліпшення регуляторної функції нервової системи $[5,7]$.

Кріотерапія - аплікації на уражену шкіру рідким азотом. Процедура проводиться через день, спрямована на відлущування змінених ділянок шкіри, має судинозвужувальну i протизапальну властивість. Із сучасних способів кріотерапії в косметології застосовують кріомасаж обличчя.

\section{Література:}

1. Амінокислотний склад видів роду Thymus L. Флори півдня України / Фуклева Л. А., Гречана.О. В., Смойловська Г. П., Мазулін О. Хімія природних сполук : матер. III Всеукр. наук.-практ. конф., 30-31 жовт. 2012. Тернопіль : Укрмедкнига, 2012. С. 49-50.

2. Вікторов О.П. Фітопрепарати: раціональний підхід домедичного застосування. Фітотерапія. 2011. № 3. С. 3-12.

3. Дослідження асортименту дерматологічних лікарських засобів для лікування інфекційних захворювань шкіри / П. П. Байва, О. С. Макарова, І. І. Баранова, Т. В. Мартинюк. Управління, економіка та забезпечення якості в фармачії.2017. № 4 (52). С. 36-41.

4. Башура А.Г., Ткаченко С.Г. Лікувальна косметика в аптеках і не тільки ... - X .: Прапор, 2006. - 392с.

5. Марголіна А, Ернандес Е. Нова косметологія. Том 1. - М .: ТОВ «Фірма Клавель», 2005. - 424 с.

6. Нова косметологія. Том 2 / За ред. Е.І.Ернандес. - М $\therefore$ ТОВ «Фірма Клавель», 2007. - 418 с.

7. Практична косметологія: навч. посібник / I.I. Медведева. 2-е видання, доп - К :. ВБО «Український Допплеровский Клуб», $2010 /-464$ c. 